\title{
Political Impacts of Tourism: A Critical Analysis of Literature
}

\author{
Chaitanya Pradeep*
}

\section{Abstract}

Tourism and politics are inexorably allied. There exists adequate literature on the nexus between political ideologies and public institutions yet, there is hardly any explicit attention paid to the field of tourism research. It may perhaps due to the impression that 'politics is all about power.' In fact, Gramscian' s notion of 'power-over' in the context of preserving cultural hegemony confines the prospects of political discourse to 'power-itself'. This notion was contested through a poststructuralist thought, 'power-to', proposed by Michel Foucault. Thus, the present paper extends the poststructuralist thought by exploring the potential areas in politics that shape the outlook of the tourism industry through a critical analysis of literature. The study argues that the associated political effects are critical to the field of tourism at the same time the tourism industry is also a potential means to promote and showcase the political ideology.

Keywords: Tourism, political ideologies, structure, instability

\section{Introduction}

The notable international agency, The United Nations World Tourism Organisation (UNWTO), in its Global Code of Ethics for Tourism stated tourists' right to travel as global. It defines the right to tourism as 'a right equally open to all inhabitants of the world'

\footnotetext{
* School of Business Studies and Social Sciences, CHRIST (Deemed to be University), Bengaluru, India; chaitanya.pradeep@ christuniversity.in
} 
and it supports the 'liberty of tourist movements' (Global Code of Ethics for Tourism, 2005). In other words, 'traveling' is a basic human right that augments the quality of life. UNWTO insists on the significant role a government can play in terms of easing tourist activities within their territories and beyond by guaranteeing its citizens the right to mobility. Further, the Manila Declaration went a little further and described tourism as a basic need, and that the state is bound to enable its citizens to participate in tourism (Manila Declaration, 2018). Nevertheless, what prevents nations from treating travel as a basic human right? Although, tourism is a universal phenomenon then why do we still have a difference of opinions on its structures and perspectives? The answer can be traced back to the deep-rooted political ideologies of the state. Apparently, political ideologies and social conditions differ from one country to another. Keeping this reality in mind, it is very important to examine not only the political ideologies but its associated political effects on tourism such as political leadership, forms of government, political systems, and international relations.

The tourism industry is a major economic, environmental, and sociocultural force and according to Richter (1982), tourism is "a highly political phenomenon". Tourism is becoming an inclusive terrain of public policy domain, especially in third-world countries. However, if we compare with third-world countries, governments of first and second world countries are much into national security, both internal and external, economy, literacy, and public health. Therefore, development policy studies have also focussed accordingly. Later, tourism also gained momentum in the process of expanding the source of income to the treasury of the government. As a result, the literature on public policy inquiries of tourism studies is often constrained by a lack of political commitment to the growth of the tourism sector. Further, tourism has hardly become a political agenda and rarely got a space in party manifesto of any national and regional political party with some exceptions. Today, political considerations count for developing tourism as a fullfledged sector. In this regard, the consistency in the political system's commitment and stability in political ideology cannot be ignored. 


\section{Theoretical Framework and Methodology}

To explore the equation between political ideologies and tourism, this paper has taken the help of poststructuralist thought. Before the application of political thought, it is important to be familiar with its related thoughts. The fundamentals of post-structuralism can be understood by making a distinction with its counterpart i.e. structuralism by referring the significant concept called 'power'. Structuralism argues that human culture can be explored by employing a structure modelled on language. Contrarily, a poststructuralism extends its consideration from object to the source of the object. This philosophy can also be extended to study the behaviour of a state and its organs like the government and its structures. Political philosophers focussed more on the concept of power while explaining the state, government, and its behaviour. For example, the theoretical framework of cultural hegemony, developed by Gramsci, defines how cultural institutions have become means to hold power in capitalist societies. This power-over perspective had become central to the political philosophy until an alternative philosophy emerged through Michel Foucault. Foucault barely looked at the "why" of power. His concentration was generally concerned with the "how" of power and focussed on "bringing to light power relations, locating their position, finding out points of applications and methods used" (Foucault, 1980). It can be interpreted as 'power to create or generate something'. This notion, 'power-to', gives a positive outlook to the concept of power and argues that power need not always be a limiting or suppressive force, it can also be a productive tool. This broad perspective paved the way to extend the scope of political studies to embrace development administration related fields including tourism. On the other hand, tourism is found to be a principle defining industry that engraves and harness places and spaces. Tourism, which concentrates largely on promoting and developing sites and sights of local, regional, and national inheritances, cultures, and histories, inevitably associated with conflictual phenomenon of actions and inactions of the State.

According to the present literature, a major portion of political studies was into power-centrism. However, few attempted were made to examine the politics and tourism nexus but they were 
mostly confined to 'political instability'. Therefore, the present paper tries to expand the arena of nexus to other ignored fundamental aspects of political system. For this purpose, the present research has adopted content analysis as a method for critically studying and analyzing the contemporary political effects with reference to tourism industry. Further, study relied completely on secondary sources that include government reports, policies, laws, journals, select case studies, and books relating to the study. Preliminary review of literature suggests the need to examine the political ideologies, political leadership, political structure, and international relations in relation to the working of tourism industry in a state.

\section{Political Ideologies and Tourism}

There are broadly three classical political ideologies. They are socialism, conservatism, and liberalism. Socialism is a political, social, and economic philosophy encompassing a range of economic and social systems characterised by social ownership (Busky, 2000). Communist ideology could be considered as an extreme form of socialism. In a country that strongly believes in communist ideology will have a complete hold over the tourism sector. This means that tourism is centrally controlled by the governmental tourism Committee (Ivanov \& Dimitrova, 2014) with strong management functions over the tourism industry of the country. Furthermore, social tourism and organised leisure for the masses will be widely prevalent. Bulgaria could be referred to as the right example of this tourism model. Nevertheless, tourism could be relatively more vulnerable in terms of being politically exploited.

North Korea remains a classic example of the aforesaid character. When it comes to a nationalist ideology which is considered as one of the elements of conservatism, the government is expected to prioritise its treatment towards encouraging inbound tourism and adopted outbound tourism as an alternative approach. In liberal countries, the role of the Ministry of Travel and Tourism remain largely a 'think tank' in terms of collecting and keeping data, researching, and offering policy inputs (Webster et al., 2011). Social democratic countries are expected to have an active governmental intervention in planning the economy, leading to state-controlled tourism. The Scandinavian countries can be referred to as examples. 
In the past three decades tourism studies has focussed on the factors that determine destination choice of tourism from the perspective of macro-environment, psychographic, and demographic (Yavas, 1987; Sonmez \& Graefe, 1998). Among the aforesaid three factors, political, economic, and ecological aspects are considered as major determinants that are generally outside the preview of the tourism industry. Therefore, variables like individual personalities, customs, and attitudes were tested to study the determinants of destination choices of tourists. As a result, literature is less in the context of demographic factors and political and policy factors compared with psychographic factors (Thorisdottir, Jost, Liviatan, \& Shrout, 2007).

There exist few studies, when it comes to exploring the relationship between political ideology and tourism, which inquired the relationship from multiple dimensions. Like, how does the political ideology of a government shapes destination choice of an individual? To inquire about this question, tourism promotional videos of government, distance, weather were used as control variables (Legg, Tang, \& Slevitch, 2012) to examine in the context of United States' destination choice. Further, liberal and conservative scales were used to measure the reported and actual politicalideological standings of the tourists and the state governments. The study is noteworthy in two proportions.

In a theoretical proportion, political ideology was tested and established as a possible destination choice secondly, it shows the likeliness between the political ideology of tourists and the destinations' political standing will help in predicting the destination choice. Thirdly, political ideologies can be a selling point as part of marketing the destination places because travellers with conservative mindset favoured destinations where conservative ideologies prevail and the same is the case with liberal travellers. Keeping these findings in mind, tourism companies can revamp their promotion and advertising policies to propagate tourists carrying certain political views. 
Table 1: Major Political Ideologies and Tourism

\begin{tabular}{|c|c|c|c|c|}
\hline Ideology & Role of the state & $\begin{array}{l}\text { Role of the } \\
\text { individual }\end{array}$ & $\begin{array}{l}\text { Priority of tourism in the } \\
\text { society }\end{array}$ & $\begin{array}{l}\text { How it should be enjoyed/ } \\
\text { supplied }\end{array}$ \\
\hline Liberalism & Limited & $\begin{array}{l}\text { Purchased and } \\
\text { enjoyed by the } \\
\text { individual }\end{array}$ & $\begin{array}{l}\text { Low, except for economic } \\
\text { development purposes }\end{array}$ & Market-supplied \\
\hline Anarchism & None & $\begin{array}{l}\text { Enjoyed } \\
\text { communally }\end{array}$ & $\begin{array}{l}\text { High, as it is linked with the } \\
\text { high value of freedom }\end{array}$ & Society-supplied \\
\hline Communism & $\begin{array}{l}\text { Provision of tourism and leisure of time } \\
\text { during dictatorship of the proletariat, no } \\
\text { role after socialist phase is past }\end{array}$ & $\begin{array}{l}\text { Enjoyed } \\
\text { communally }\end{array}$ & $\begin{array}{l}\text { High, as it is linked with } \\
\text { entitlements of the working } \\
\text { class }\end{array}$ & $\begin{array}{l}\text { State-supplied, society-supplied } \\
\text { (in later historical stages) }\end{array}$ \\
\hline $\begin{array}{l}\text { Social } \\
\text { democracy }\end{array}$ & $\begin{array}{l}\text { Provision of legal framework to ensure } \\
\text { leisure and tourism opportunities, state } \\
\text { regulation to ensure leisure and tourism }\end{array}$ & $\begin{array}{l}\text { Purchased and } \\
\text { enjoyed by the } \\
\text { individual }\end{array}$ & $\begin{array}{l}\text { High, as it is linked with } \\
\text { entitlements of the working } \\
\text { class }\end{array}$ & $\begin{array}{l}\text { Mostly market-supplied but such } \\
\text { supply ensured by substantial } \\
\text { state interventions into the market }\end{array}$ \\
\hline $\begin{array}{l}\text { Fascism/ } \\
\text { National } \\
\text { Socialism }\end{array}$ & $\begin{array}{l}\text { Provision of legal framework to ensure } \\
\text { leisure and tourism opportunities, state/ } \\
\text { party intervention to ensure leisure and } \\
\text { tourism }\end{array}$ & $\begin{array}{l}\text { Provided by the } \\
\text { state and market } \\
\text { and enjoyed } \\
\text { communally }\end{array}$ & $\begin{array}{l}\text { High, as it is linked with a } \\
\text { system of rewards for the } \\
\text { loyalty of the working } \\
\text { classes }\end{array}$ & $\begin{array}{l}\text { Mixture of state and market forces } \\
\text { supplying tourism opportunities }\end{array}$ \\
\hline
\end{tabular}

Source: Craig Webster and Stanislav Ivanov, 2015, p.112

A similar kind of study was conducted by Craig Webster and Stanislav Ivanov. The purpose of this paper was to identify the link between political ideology and the management of tourism in countries. The authors stipulate that the predominant political ideology in the country influences the nature and logic of state interventions in the tourism industry. Methodologically, the paper elaborates on several case studies from various countries like Bulgaria, Cyprus, Scandinavia, Russia, USA, China, Japan, Indonesia, and North Korea. Findings suggest that countries with predominant neo- liberal ideology do not typically interfere in tourism regulation, while nationalism leads governments to stimulate inbound and domestic tourism. Communist ideological approaches tend to be arduous, inhibiting growth while stressing the promotion of the socialist achievements of a country. Countries that are traditionally thought of as social-democratic have been evolving in recent years to regulate tourism in ways that are more liberal in nature than social democratic (Webster \& Ivanov, 2015). However, there exist some practical implications. Political ideologies shape the acceptability of government support for private tourist companies, legislation in the field of tourism, limitation/stimulation of inbound/outbound tourist flows. For the future, the authors expect greater politicisation of tourism, active tourism "wars" between countries, greater control of governments on populations, thriving nationalism, and "aggressive" environmentalism.

To sum up, different ideologies gives different perspective towards the concept of tourism. One can notice that the role of the state in the 
regulation and provision of tourism varies a great extent by the political ideology adhered to. For example, the Indian political system is sensitive to permit casinos as tourist attractions. Contrarily, some governments turn a blind eye towards sex tourism and prostitution while other governments formulate strict laws against the same. Apparently, regulation of tourism is particularly acute in fascist and communist political systems, while there is some involvement in this in social democratic approaches. Another interesting observation is that liberal and social democratic approaches put significant stress on the importance of market forces.

\section{Political structures and tourism}

The influence of political ideologies over the tourism industry can be explicated through the structures of varied states. Political ideologies not only shape the form of government and its organisational structure but also determine the role of government in developing the tourism industry. For instance, in a Union form of state, the organization and hierarchy of a government will be highly centralised than that of the Federal state. In Thailand, there exists a unified tourism policy across the country but in a quasi-federal state like India, state governments and local self-governments at grassroot level can design its own policies that may differ with Union government's policy. Political ideologies would reflect in the approach of the state towards what extent of tourism required to develop and what type of management needed i.e. integral or managerial. Therefore, it can be understood that ideological factors will be considered at the organizational planning stage itself. In this context, the public policy perspective will also help to examine the relation between political ideologies and tourism. After a thorough review of tourism policies of different governments, literature suggests that the outcomes of tourism planning will be shaped typically by the nation's ideology and its constitutional directions towards achieving socio-economic and political goals (Gunn, 1988). Accordingly, tourism policies cannot have a deviation from the broader socio-economic and cultural policies of the country. Further, this will reflect in the state vs market debate which means, relative roles of government and private sectors in terms of its investment, management, partnership, sharing profits etc. 


\section{Political leadership and tourism}

The role of political leadership in the tourism industry within the political arena cannot be ignored. Leadership is a concept that has been the focus of explorations in a multitude of fields, including. tourism (Beritelli, 2011; Pechalner, Kozak, \& Volgger, 2014; Zach, 2013). These studies have yielded many definitions of leadership with several authors emphasizing that it is "the ability to influence a group toward the achievement of goals" (Robbins, 2000). In the context of tourism, leaders who work towards gaining political consensus for the industry must influence two groups, the members of the tourism industry and policymakers.

Leaders influence tourism industry members to unite around common interests and agree upon a legislative agenda (McGehee \& Meng, 2006). Tourism leaders then advocate for the industry based upon this legislative agenda as they attempt to influence policymakers. Thus, political leaders in the tourism industry can be considered tourism advocates. Swanson and Brothers (2012) illustrate the complex roles tourism advocates play in voicing the industry's diverse interests in Federal-level policymaking and McGehee and Meng (2006) demonstrate their value in gaining influence at the State-level. Despite the vital role that they play in gaining political support for the tourism industry, there has been relatively limited exploration of tourism advocates and how they achieve influence among the industry and policymakers. Therefore, Whitney Knollenberg (2015) introduced a framework that may prove useful for research efforts related to political leadership in tourism, which in turn can yield valuable findings to support the development of future tourism advocates. The author proposed a model of political leadership for the tourism industry. While presenting a paper titled "An Introduction to a Model of Political Leadership in the Context of Tourism Advocates" it was expressed that the traits and styles of tourism advocates are important components in understanding how they influence members of industry and policymakers. Also, a more detailed profile of tourism advocates is needed if we are to fully explore their ability to gain political support for tourism. 
While the traits and styles of tourism advocates are important components in understanding how they influence members of industry and policymakers, a more detailed profile of tourism advocates is needed to explore their ability to gain political support for tourism. Therefore, Whitney Knollenberg (2015) focused on a modified version of a model of political leadership, a comprehensive framework illustrating the contextual elements and antecedents that influence leadership behaviours and their outcomes for both the leaders and their target audiences (e.g. tourism industry members or policymakers) (Ammeter, Douglas, Gardner, Hochwater, and Ferris, 2002). Guided by a thorough literature review this model was adapted for use in the context of tourism by exploring previous work that identified the role of leadership in getting political influence for the tourism industry (Hall, 1994; McGehee \& Meng, 2006). The existing literature revealed multiple similarities between Ammeter et al's (2002) model and the proposed role and value of tourism advocates. For example, previous explorations of political activity in tourism have revealed that it is vital that the industry speaks with a unified voice on legislative issues (McGehee \& Meng, 2006). Thus, a tourism advocate may seek the creation of a unified voice as an outcome of their political behaviours. This could require changing the attitudes of tourism industry members to support the legislative agenda which the advocates will present to policymakers. The fragmented nature of the tourism industry makes such an outcome difficult to achieve, and thus an understanding of what leads to creating a unified voice would be valuable. The creation of a unified voice is just one example of an outcome that tourism advocates may attempt to achieve, others such as fostering methods of communication (Stevenson, Airey, \& Miller, 2008) and cultivating collaboration and negotiation (Bramwell \& Meyer, 2007) are also important but challenging to accomplish.

\section{International relations and tourism}

The literature on tourism is broadly categorised into 'pro-tourism' and 'anti-tourism'. This dichotomy is predominantly evident in the context of cultural, environmental, and economic tourism. The protourism approach carried a positive externality, treats global cultural exchange to construct international relations, enhancing the sense of 
ecologism, and welfare of the destination countries. Since the 1960s, international institutions such as the Organisation for Economic Cooperation and Development (OECD), the United Nations, and the World Bank have expressed the massive social and economic potential of tourism for developing countries. However, treating travel and tourism as major global economic phenomena is not a new trend in tourism studies and today it has received the status of a 'post-industrial activity'. It is too early to characterise the nature of the tourism sector in the developing world. Notwithstanding this, third world countries are being attracted to promote the tourism industry in their respective countries. By the end of 2012, Latin America, Asia and sub-Sahara Africa were among the fastest evolving destination markets (UNWTO Report, 2012). Tourism as an industry is considered as one of the most attractive and promising sectors for underdeveloped countries. Further, to enhance the potential of this industry, the cooperation and support from the UN, UNESCO, and the World Bank is inevitable. But the imposition of developed countries' political ideologies may possibly not allow that to happen. Tourism can reasonably address the major concerns of third world economies' unemployment, low income, poor infrastructure, etc. However, the actual benefits to the Third World economies from mass tourism are highly contested. American President Donald Trump's policies on immigration and travel are nothing but the reflection of the political ideology the government believes in. Though, it could influence the tourism sector the government did not bother to issue Executive Order 13769. Later, the country has seen a certain slow down in its income in that year (CEO and president of the World Travel \& Tourism Council (WTTC), 2017).

\section{Political instability and tourism}

It is the political system and its stability that constitutes the fundamental platform for any industrial growth including tourism. The political system, primarily includes continuity of government for a fixed period. But in a broader sense, it forms politicians, legislators, bureaucrats, and others involved in policy formulation. The concept of Political instability is a complex term with multiple folds (Gupta, 1990). There exists a need to critically look at the factors 
that determine the nexus between political instability and tourism development. Thus, tourism industry becomes one of the most vulnerable sectors during the political instability (Theocharous, Nuttal \& Sedderland 2000).

Political instability is described as a condition of a country where a government has been toppled or is controlled by factions following a coup, or where basic functional pre-requisites for social-order control and maintenance are unstable and periodically disrupted (Cook, 1990cited in Sonmez, 1998). In the context of international tourism, political instability can be caused due to international and civil wars, coups, terrorism, riots, political and social unrest, and strikes (Lea \& Small, 1988 cited in Hall \& O'Sullivan, 1996). There is hardly any study exists that inspects the connection between political instability and tourism. The reasons could be listed in the following manner: there exists a reluctance in the minds of policy stakeholders in government and in the private sector to acknowledge the political nature of tourism; lack of academic interest especially by social science scholars in researching the politics of tourism; overinfluence of management studies on tourism studies and lastly, tourism is not regarded as a serious scholarly subject (Richter, 1983a \& 1991; Hall, 1989; Matthews, 1991). From the point of business, political stability is of extreme importance to any investment, but it is of distinct consequence to the tourism industry due to what is being traded- adventure, a distinct excitement, experience, and leisure. These can be traded only in the presence of stable political conditions. Tourist arrivals are a barometer not only of a nation's currency relative to other currencies but also of the safe perception of a nation (Richer, 1994 cited in Cothran, 1998).

\section{Using tourism as a tool for political objectives}

The tourism industry is often seen as a means of accomplishing political ends such as increased economic development and is shaped by political activity through funding allocation and legislation (Hall, 1994). Tourism could be used as a political weapon by some countries against others, where governments can exert political pressure through tourism and use it as a promotional vehicle to convey a positive image or as a sanction against others (Sonmez, S.F., 1998). The case study of the Philippines offers an idea 
of how political instability throws challenges to the growth of its tourism sector. Soon after receiving freedom from America in 1965, Marcos' leadership failed to provide stability of governance to the Philippines. This administrative inefficiency caused not only political instability but also economic crisis. The government had imposed Martial Law in the year 1972, as part of bringing the political and economic conditions under, but projected this imposition by Marcos as a "new society" (Hall \& Oehlers, 2000). This imposition of Martial Law paved a way for Marcos government to bring radical changes in tourism sectors through various programmes (Ricther, 1989). The tourism sector was given high priority in terms of granting budget. The hidden agenda was to attract more tourists through which the government can claim legitimacy by showcasing the rise in tourist arrivals to the public. Besides, the government tried to use tourists to generate a positive image in favour of the government, like expressing a sense of security when the tourists visited and asking people from other countries to visit. Precisely, the government used the tourism sector as a political means (Ricther, 1989 cited in Hall and Oehlers, 2000). However, Marcos's political tactic had no respectable conclusion. During the American Society of Travel Agents Conference held in 1980, there was a failed bomb attack on Marcos which in turn had a negative impact on tourist visitation from the USA. This incident along with corruption charges distorted Philippines tourism into a political liability for his regime (Ricther 1989).

\section{Conclusion}

Based on the review of available literature, it can be observed that political ideologies profoundly shape the role of the government either actively or passively towards the tourism sector. For instance, formulating rigid visa rules would discourage the choice that tourists are making. Further, restrictions on the employment of foreign nationals, flexible investment policies, bilateral agreements on air services, and preferential treatment towards domestic and outbound tourism indicate the degree of political ideology the government believes in. However, critical analysis of political intensions of governments suggests that tourism can be used as a means for achieving political ends. The crucial question is 'how to 
prevent this?' Today, there is a paradigm shift in the form of control by the governments because now the role of Tourism Ministries is reduced to facilitators. The intervention of New Public Management convinced many countries irrespective of the ideology they believe to adopt business-like principles and venture into public-private partnership. Yet, the role of government cannot be overlooked.

\section{References}

Alcantara, N. (2012). Eturbonews.Com. http:// www.eturbonews.com/ 53579/ brand-usa-s-renewal-touted-triumph-americas-economy.

Ammeter, A. P., Douglas, C., Gardner, W. L., Hochwarter, W. A., \& Ferris, G. R. (2002). Toward a political theory of leadership. The Leadership Quarterly, 13(6), 751-796.

Andriole, S., \& Hopple, G. (1984). Revolution and Political Instability. Frances Pinter.

Beritelli, P. (2011). Cooperation among prominent actors in a tourist destination. Annals of Tourism Research, 38(2), 607-629.

Bramwell, B., \& Meyer, D. (2007). Power and tourism policy relations in transition. Annals of Tourism Research, 34(3), 766-788.

Busky, D. F. (2000). Democratic Socialism: A Global Survey. Praeger. p. 2. Gunn, C. A. (1988). Tourism Planning. Taylor \& Francis.

Cothran, D. A., \& Cothran, C. C. (1998). Promise or Political Risk for Mexican Tourism Annals of Tourism Research 25(2), 477-497.

Webster, C., \& Ivanov, S. (2015). Political ideologies as shapers of future tourism development. Journal of Tourism Future, 109-124.

Overtourism - Is travel a right? The concept of right, \& when it's just wrong. (n.d.). Retrieved June 28, 2020, from https:// www. responsibletravel.com/copy/overtourism-is-travel-a-right and https:// www.univeur.org/ cuebc/downloads/ PDF\% 20carte/ 65.\%20Manila.PDF

Ferris, G. R. (2002). Toward a political theory of leadership. The Leadership Quarterly, 13(6), 751-796.

Foucault, M. (1978). The History of Sexuality. Vintage Books.

Foucault, M. (1980). Power/Knowledge ed. by Colin Gordon. Pantheon Books.

Foucault, M. (1983). "Subject and Power" in Hubert Dreyfus and Paul Rainow Michel.

Foucault, M. (1995). Discipline and Punish 2nd ed. Vintage Books.

Gramsci, A. (1975). History, Philosophy and Culture in the Young Gramsci. Published by Telos Press. 
Gramsci, A. (1980). Selections from the Prison Notebooks. 6th ed. Wishart Publications.

Gupta, D. (1990). The Economics of Political Instability: The Effect of Political Instability on Economic Growth. Praeger.

Seddighi, H.R. and Theocharous, A.L., (2002). Tourism Management, 23, 475487

Hall, C. M. (1994). Tourism and politics: policy, power and place. John Wiley \& Sons.

Hall, C. M. (1996). Tourism and Politics: Policy, Power and Place. John Wiley \& Son Ltd.

Hall, C.M. (2001). Tourism and Political Relationships in Southeast Asia. In P. Teo, T.C. Chang and K.C. Ho (eds.) Interconnected Worlds Tourism in Southeast Asia. Pergamon.

Legg, M. P., Tang, C. H., Slevitch, L. (2012). Does Political Ideology Play a Role in Destination Choice? American Journal of Tourism Research, 1(2), 45-58

McGehee, N., \& Meng, F. (2006). The politics of perception: Legislative images of the tourism industry in Virginia and North Carolina. Journal of Travel Research, 44(4), 368 - 378.

Pechlaner, H., Kozak, M., \&Volgger, M. (2014). Destination leadership: a new paradigm for tourist destinations? Tourism Review, 69(1), 1-9.

Richter, L., 1989. The Politics of Tourism in Asia. University of Hawaii Press.

Robbins, S. (2000). Organizational Behavior: Concepts-controversiesapplications (8th ed.). Englewood Cliffs, Prentice Hall.

Sanders, D. (1981). Patterns of Political Instability. MacMillan.

Seddighi, M. R., Nuttall, M. W., \& Theocharous, A. L. (2001). Does Cultural Background of Tourists Influence the Destination Choice? An Empirical Study with Special Reference to Political Instability. Tourism Management, 22, 181-191.

Siegel, B. (2009). What Happens When You Stop Marketing: The rise and fall of Colorado tourism. Retrieved from: http://www.longwoodsintl.com/wp content/uploads/2010/11/The_Rise_and_Fall_of_Colorado_Tourism .pdf [accessed 19 March 202]

Sonmez, S., \& Graefe, A. R. (1998). Influence of Terrorism Risk on Foreign Tourism Decisions. Annals of Tourism Research, 25(1), 112-144.

Sonmez, S.F. (1998). Tourism, terrorism and political instability. Annals of Tourism Research, 25, 416-456

Stevenson, N., Airey, D., \& Miller, G. (2008). Tourism Policy Making: The Policymakers; Perspectives. Annals of Tourism Research, 35(3), 732-750.

Webster, C., \& Ivanov, S. (2014). Tourism as a force for political stability. In Wohlmuther, C. and Wintersteiner, W. (Eds), The International Handbook on Tourism and Peace, Drava Verlag., \& Klagenfurt/celovec., 167-180 
Yardley, W. (2011). A Tourism Office Falls Victim to Hard Times, New York Times. Retrieved from http:// www.nytimes.com/ 2011/ 07/ 12/us/12tourism.html?_r=0

Zach, F. (2013). Collaboration for Innovation in Tourism Organizations: Leadership Support, Innovation Formality, and Communication. Journal of Hospitality and Tourism Research. Volume: 40 (3), 271-290. 